\author{
AnNA KAPAEA ${ }^{1}$
}

\title{
Prawne uwarunkowania wsparcia krótkich łańcuchów dostaw żywności w PROW 2014-2020
}

Krótkie łańcuchy dostaw i lokalne systemy żywnościowe od zawsze istniały, jednak wcześniej nie były przedmiotem zainteresowania Unii Europejskiej w takim stopniu, jak w obecnej polityce rozwoju obszarów wiejskich. Ich rola w poprawie konkurencyjności producentów rolnych została wyraźnie uwzględniona w ramach celu szczegółowego 3A, zdefiniowanego w rozporządzeniu UE 1305/2013. ${ }^{2}$ Ponadto prawo UE po raz pierwszy wprowadziło definicję ,krótki łańcuch dostaw żywności” w art. 2 wspomnianego rozporządzenia.

Polski Program Rozwoju Obszarów Wiejskich na lata 2014-2020 będzie realizował wszystkie sześć priorytetów wyznaczonych w nowym okresie programowania dla unijnej polityki rozwoju obszarów wiejskich, w tym priorytet $\mathrm{nr} 3$, tj. „wspieranie organizacji łańcucha żywnościowego, przetwarzania i wprowadzania do obrotu produktów rolnych", a w ramach niego wspomniany cel szczegółowy 3 a.

Poprawie funkcjonowania łańcucha żywnościowego służy wiele działań, określonych w PROW. Mają one wspierać ,integrację poziomą rolników, czyli działania zespołowe producentów pozwalające na osiągnięcie korzyści skali, oraz integrację pionową prowadzącą do wchodzenia producentów rolnych w kolejne fazy łańcucha żywnościowego takie jak przetwórstwo na małą skalę czy sprzedaż bezpośrednio do konsumenta, co umożliwi rolnikom przejmowanie marży przetwórczej oraz detalicznej". ${ }^{3}$

Omówienie powyższych działań pozwoli przybliżyć formy skracania łańcucha żywnościowego, dla których zostało przewidziane wsparcie, a analiza prawnych

Uniwersytet Przyrodniczy we Wrocławiu.

Priorytety unijne w zakresie rozwoju obszarów wiejskich określone są w art. 5 rozporządzenia Parlamentu Europejskiego i Rady (UE) nr 1305/2013 z dnia 17 grudnia 2013 r. w sprawie wsparcia rozwoju obszarów wiejskich przez Europejski Fundusz Rolny na rzecz Rozwoju Obszarów Wiejskich (EFRROW) i uchylające rozporządzenie Rady (WE) nr 1698/2005, Dz.Urz. UE L $347 / 487$ z 20 grudnia 2013 r. Cel szczegółowy 3a dotyczy „poprawy konkurencyjności producentów rolnych poprzez lepsze ich zintegrowanie z łańcuchem rolno-spożywczym poprzez systemy jakości, dodawanie wartości do produktów rolnych, promocję na rynkach lokalnych i krótkie cykle dostaw, grupy i organizacje producentów oraz organizacje międzybranżowe". PROW 2014-2020, s. 48. 
uwarunkowań jego uzyskania ma na celu ustalenie, czy są one spójne z obowiązującym ustawodawstwem, a zwłaszcza ze znowelizowanymi przepisami o sprzedaży bezpośredniej. Ta ostatnia jest bowiem jedną z form skracania łańcuchów dostaw żywności, prawnie uregulowaną, w której mogą uczestniczyć rolnicy, bez konieczności rejestracji działalności gospodarczej. ${ }^{4}$

W pierwszej kolejności zostaną omówione inwestycje, które w ramach ogólnego celu skracania łańcucha dostaw, skierowane są wprost na wsparcie sprzedaży bezpośredniej produktów rolnych, także przetworzonych, prowadzonej przez rolników, takie jak „Inwestycje w targowiska lub obiekty budowlane przeznaczone na cele promocji lokalnych produktów”, „Pomoc na rozpoczęcie działalności gospodarczej na rzecz rozwoju małych gospodarstw”, „Wsparcie inwestycji w gospodarstwach rolnych”, „Inwestycje w przetwarzanie produktów rolnych, obrót nimi lub ich rozwój”, „Pomoc w rozpoczęciu działalności gospodarczej na rzecz młodych rolników” oraz „Systemy jakości produktów rolnych i środków spożywczych”. Następnie przybliżone zostaną działania, mające na celu integrację podmiotów łańcucha żywnościowego, tj. „Tworzenie grup i organizacji producentów”, „Współpraca”, „Leader”, które wzmacniają pozycję producenta rolnego w łańcuchu żywnościowym i przyczyniają się do budowania lokalnego systemu żywnościowego.

Działanie wprost skierowane na wsparcie sprzedaży bezpośredniej żywności oraz skracanie łańcucha dostaw to „Inwestycje w targowiska lub obiekty budowlane przeznaczone na cele promocji lokalnych produktów” (w ramach działania „Podstawowe usługi i odnowa wsi na obszarach wiejskich"). Beneficjentem działania moga być gminy do 200 tys mieszkańców. Trudno zrozumieć, jakie jest uzasadnienie takiego ograniczenia. Nie zostało ono określone w art. 20 rozporządzenia 1305/2013 będącym podstawą prawną powyższego działania. Wydaje się, że byłoby wskazane zwiększenie powyższego progu do większych gmin, tym bardziej że właśnie w nich utrudniony jest dostęp do lokalnych produktów prosto od rolnika, przy równoczesnym dużym na nie popycie.

Pozytywnie należy ocenić przewidywaną preferencję dla targowisk, w których większy jest udział powierzchni handlowej przeznaczonej dla rolników w stosunku do całkowitej powierzchni targowiska. Są to zatem rozwiązania zbliżające do istniejących w innych państwach rynków chłopskich, tzw. farmers' markets i są spójne z niedawno uchwalonymi przepisami, zmieniającymi art. 3 u.s.d.g., zezwalającymi sprzedaż bezpośrednią przetworzonych w sposób inny niż przemysłowy produktów roślinnych i zwierzęcych pochodzących z własnej uprawy, hodowli lub chowu w miejscach, w których produkty te zostały wytworzone oraz na targowiskach, z wyjątkiem budynków. Zob. ustawę z dnia 9 kwietnia 2015 r. o zmianie ustawy o podatku dochodowym od osób fizycznych oraz niektórych innych ustaw (Dz.U. z 2015 r., poz. 699), która m.in. zmieniła art. 3 ustawy z dnia 2 lipca 2004 r. o swobodzie działalności gospodarczej, Dz.U. z 2004 Nr 173, poz. 1807 ze zm. (dalej powoływanej jako u.s.d.g.) którego nowe brzmienie wejdzie w życie od dnia 1 stycznia $2016 \mathrm{r}$. 
rolnikowi na sprzedaż tylko w dwóch miejscach, tj. w gospodarstwie i na targowisku.

Realizacją i rozwinięciem założeń PROW powinny być regulacje prawne sprzyjające tworzeniu rynków chłopskich, gwarantujące udział w nich producentom rolnym i ustalające jednolite wymogi i standardy ich realizacji. Być może zostaną one określone w ramach rozporządzenia, ${ }^{5}$ warto jednak rozważyć wprowadzenie rozwiązania ogólnego, obowiązującego nie tylko w ramach realizacji PROW, określającego także jednolite wymogi w zakresie etykietowania i wskazywania miejsca pochodzenia produktu. W odniesieniu do tej ostatniej kwestii wydaje się, że przydatne byłoby normatywne określenie na poziomie krajowym czytelnego logo lub znaku dla produktów lokalnych pochodzących prosto od rolnika.

Innym ważnym działaniem wspierającym podejmowanie przez rolników sprzedaży bezpośredniej jest „Restrukturyzacja małych gospodarstw”, poddziałanie „Pomoc na rozpoczęcie działalności gospodarczej na rzecz rozwoju małych gospodarstw". Pomoc jest przyznawana na restrukturyzację gospodarstwa w kierunku produkcji żywnościowych lub nieżywnościowych produktów rolnych, a także przygotowania do sprzedaży produktów rolnych wytwarzanych w gospodarstwie, przy czym projekt rozporządzenia nie precyzuje wprost, w przeciwieństwie np. do warunków działania „Wsparcie inwestycji w przetwarzanie produktów rolnych, obrót nimi lub ich rozwój," czy kwalifikuje się również sprzedaż detaliczna.

Beneficjentem może być rolnik będący osobą fizyczną ubezpieczoną na podstawie przepisów o ubezpieczeniu społecznym rolników z mocy ustawy i w pełnym zakresie jako rolnik, prowadzącą wyłącznie działalność rolniczą, w celach zarobkowych w zakresie produkcji roślinnej lub zwierzęcej. W rozumieniu projektu rozporządzenia działalność rolnicza prowadzona jest przez osobę fizyczną w sposób zarobkowy, jeżeli w okresie 12 miesięcy poprzedzających miesiąc złożenia wniosku o przyznanie pomocy uzyskała ona przychód ze sprzedaży produktów rolnych w wysokości co najmniej 5 tys. zł, udokumentowany fakturą VAT lub fakturą VAT $\mathrm{RR}$, lub wydrukiem paragonu fiskalnego kas rejestrujących, lub dokumentacją podatkową podatku dochodowego od osób fizycznych. ${ }^{6}$

Z powyższego wynika, że rolnik ubiegający się o pomoc na ,przygotowanie do sprzedaży produktów rolnych wytwarzanych w gospodarstwie" de facto już wcześniej musi prowadzić działalność sprzedaży produktów rolnych i otrzymywać z tego tytułu, jako tzw. rolnik ryczałtowy, faktury VAT RR od podatników VAT czynnych lub wystawiać faktury VAT jako podatnik VAT czynny lub odprowadzać podatek spodarstw” w ramach poddziałania „Pomoc na rozpoczęcie działalności gospodarczej na rzecz małych gospodarstw” objętego Programem Rozwoju Obszarów Wiejskich na lata 2014-2020. 
dochodowy z tytułu sprzedaży produktów rolnych. Ten ostatni warunek dziwi, skoro sprzedaż produktów rolnych nie podlega opodatkowaniu, a jedynie sprzedaż produktów przetworzonych (i tylko do końca 2015 r.). ${ }^{7}$ Zaś posiadanie kasy fiskalnej wymagane jest tylko od podatników, którzy przekroczą określone w przepisach limity obrotu ze sprzedaży towarów i usług. ${ }^{8}$ Biorąc pod uwagę, że wsparcie skierowane jest do małych gospodarstw rolnych, dla wielu z nich powyższy wymóg udokumentowania prowadzenia zarobkowej sprzedaży może stanowić problem.

Kryteria przewidziane dla omawianego działania w PROW, jak również w projekcie rozporządzenia, nie przewidują obowiązku zarejestrowania działalności gospodarczej. Ponadto przyznawane są preferencje ze względu na m.in. przetwarzanie produktów rolnych wytwarzanych w gospodarstwie. Należy zauważyć, że chociaż warunki działania nie odnoszą się wprost do „sprzedaży bezpośredniej”, to tylko w takiej formie, zgodnie ze znowelizowanym art. 3 u.s.d.g., rolnik może zbyć swoje produkty przetworzone, tj. konsumentowi, w miejscu prowadzenia produkcji lub na targowiskach. Jest to zatem instrument zachęcający małe gospodarstwa do wejścia w kolejne fazy produkcji, który wpisuje się w treść wspomnianego przepisu, umożliwiającego rolnikom przetwarzanie własnych produktów.

Preferencje przyznawane są także ze względu na udział w zorganizowanych formach współpracy producentów rolnych. Niestety w zakresie przetwarzania i sprzedaży bezpośredniej znowelizowany art. 3 u.s.d.g. nie umożliwia współpracy między rolnikami, zastrzegając, że mogą oni przetwarzać i sprzedawać wyłącznie produkty roślinne i zwierzęce pochodzące $\mathrm{z}$ własnej uprawy, hodowli lub chowu. W ofercie sprzedaży nie mogą zatem znaleźć się produkty pochodzące od innego rolnika lub których przetworzenie odbyło się w innym gospodarstwie rolnym.

Po uzyskaniu wsparcia musi nastąpić, w wyniku restrukturyzacji gospodarstwa, wzrost wielkości ekonomicznej gospodarstwa do poziomu minimum 10 tys. euro i o $20 \%$ w stosunku do sytuacji wyjściowej. Wzrost powinien być utrzymany do dnia upływu 5 lat od dnia wypłaty pierwszej raty pomocy. Ponadto beneficjent będzie musiał prowadzić ewidencję przychodów i rozchodów w gospodarstwie lub księgę przychodów i rozchodów, lub księgę rachunkową najpóźniej od dnia rozpoczęcia realizacji biznesplanu przez co najmniej 5 lat od dnia wypłaty drugiej raty pomocy. Ten warunek jest bardziej rygorystyczny niż nowe przepisy w zakresie sprzedaży bezpośredniej, bowiem art. 20 ust. 1c pkt 4 u.p.d.o.f., który wejdzie w życie od

Zobacz art. 20 ust. 1 c w brzmieniu obowiązującym od dnia 1 stycznia 2016 r. ustawy z dnia 26 lipca 1991 r. o podatku dochodowym od osób fizycznych (Dz.U. z 1991 r. Nr 80, poz. 350 z późn. zm.), dalej powoływanej jako u.p.d.o.f.

Zob. Rozporządzenie Ministra Finansów z dnia 4 listopada 2014 r. w sprawie zwolnień z obowiązku prowadzenia ewidencji przy zastosowaniu kas rejestrujących (Dz.U. poz. 1544) oraz art. 111 ustawy z dnia 11 marca 2004 r. o podatku od towarów i usług (Dz.U. Nr 54, poz. 535 z późn. zm.). Zgodnie z powyższym rozporządzeniem z obowiązku posiadania kas fiskalnych zwolnieni są rolnicy ryczałtowi dokonujący dostawy produktów rolnych pochodzących z własnej działalności rolniczej lub świadczących usługi rolnicze, korzystających ze zwolnienia od podatku na podstawie art. 43 ust. 1 pkt 3 ustawy. 
1 stycznia 2016 r., przewiduje obowiązek prowadzenia przez rolnika uproszczonej ewidencji sprzedaży produktów roślinnych i zwierzęcych.

Kolejnym działaniem wspierającym przygotowanie gospodarstwa do sprzedaży produktów rolnych jest „Modernizacja gospodarstw rolnych”, poddziałanie „Wsparcie inwestycji w gospodarstwach rolnych". Pomoc udzielana jest na materialne lub niematerialne inwestycje poprawiające ogólne wyniki (ogólną wydajność) gospodarstw rolnych prowadzących zarobkową działalność rolniczą, które będą przyczyniały się do poprawy konkurencyjności i zwiększenia rentowności gospodarstwa rolnego w wyniku jego restrukturyzacji, opartej o orientację rynkową.

Pomoc przyznaje się na zwiększenie rentowności i konkurencyjności gospodarstw w obszarze produkcji lub na operację obejmującą wyłącznie inwestycje związane bezpośrednio z działalnością rolniczą, w tym również przygotowaniem do sprzedaży produktów rolnych wytwarzanych w gospodarstwie. ${ }^{9}$ Rozporządzenie nie precyzuje, czy chodzi o sprzedaż bezpośrednią do konsumenta końcowego, czy o sprzedaż hurtową, będącą naturalną końcową fazą produkcji rolniczej.

Beneficjentem mogą być tylko rolnicy (lub grupa rolników) prowadzący działalność rolniczą w celach zarobkowych. Rozporządzenie w taki sam sposób, jak w wyżej omówionym działaniu, wyjaśnia pojęcie „działalność rolnicza prowadzona w celach zarobkowych". Jak wspomniano, małe gospodarstwa, prowadzące działalność rolniczą na samozaopatrzenie lub w niewielkim zakresie działalność sprzedaży mogą mieć trudności w udokumentowaniu zarobkowej działalności, przez co nie będą mogły skorzystać ze wsparcia. Ale omawiane działanie nie jest do nich skierowane, bowiem kryteria wyboru kwalifikują do pomocy, w przeciwieństwie do poprzedniego działania, większe gospodarstwa rolne, tj. o wielkości ekonomicznej od 10 tys. euro i nie większej niż 200 tys. euro.

Poddziałanie „Wsparcie inwestycji w przetwarzanie produktów rolnych, obrót nimi lub ich rozwój” (w ramach działania „Przetwórstwo i marketing produktów rolnych") zostało skierowane specjalnie na inwestycje związane z przetwarzaniem i sprzedażą detaliczną podejmowane przez rolników lub ich domowników, lub małżonka rolnika rozpoczynających prowadzenie działalności przetwarzania produktów rolnych. ${ }^{10}$ Działanie to dobrze wpisuje się w nowe przepisy umożliwiające rolnikom prowadzenie przetwarzania i sprzedaży bezpośredniej produktów. Ponadto

Szerzej zob. § 4 rozporządzenia Ministra Rolnictwa i Rozwoju Wsi z dnia 21 sierpnia 2015 r. w sprawie szczegółowych warunków i trybu przyznawania oraz wypłaty pomocy finansowej na operacje typu „Modernizacja gospodarstw rolnych" w ramach poddziałania „Wsparcie inwestycji w gospodarstwach rolnych” objętego Programem Rozwoju Obszarów Wiejskich na lata 2014-2020, Dz.U. poz. 1371.

Zob. $\S 2$ ust. 1 pkt 2 rozporządzenia Ministra Rolnictwa i Rozwoju Wsi z dnia 5 października 2015 r. w sprawie szczegółowych warunków i trybu przyznawania oraz wypłaty pomocy finansowej w ramach poddziałania „Wsparcie inwestycji w przetwarzanie produktów rolnych, obrót nimi lub ich rozwój" objętego Programem Rozwoju Obszarów Wiejskich na lata 2014-2020, Dz.U. poz. 1581. 
beneficjentem mogą być również mikro-, mali i średni przedsiębiorcy rozpoczynający działalność gospodarczą w zakresie przetwórstwa i sprzedaży. ${ }^{11}$

Pomoc przyznaje się w formie refundacji 50\% kosztów kwalifikowalnych projektu. W przypadku przedsiębiorców są to koszty poniesione na budowę lub modernizację zakładów przetwórstwa produktów rolnych lub infrastruktury handlu hurtowego produktami rolnymi. Rolnik, domownik lub małżonek rolnika może wnioskować o refundację kosztów operacji związanych ze sprzedażą detaliczną, wraz z zakupem maszyn i urządzeń do przetwarzania lub magazynowania produktów rolnych do wysokości 300 tys. zł, określonej w $§$ ust. 5 ust. 7 pkt 3 rozporządzenia.

Analizowane działanie, w przeciwieństwie do dwóch omówionych powyżej nie uzależnia przyznania wsparcia od wielkości gospodarstwa, nie wymaga wzrostu wielkości ekonomicznej gospodarstwa ani prowadzenia działalności rolniczej w sposób zarobkowy, nie przewiduje też obowiązku prowadzenia księgi przychodów i rozchodów, lub księgi rachunkowej, lub ewidencji przychodów i rozchodów.

Warto zwrócić uwagę na ciekawy przepis zobowiązujący przedsiębiorstwa do zaopatrywania się co roku, w co najmniej 50\% całkowitej ilości surowców niezbędnych do produkcji, u producentów rolnych, grup lub organizacji producentów, związków grup lub zrzeszeń organizacji producentów lub podmiotów wstępnie przetwarzających produkty rolne, na podstawie co najmniej 3-letnich umów, zawierających mechanizm ustalania cen nabycia produktów rolnych. Drugie zobowiązanie polega na wykorzystywaniu do zamrażania i przechowywania produktów rolnych, na podstawie umów zawieranych co najmniej na 3 lata z producentami rolnymi lub podmiotami, które nabywają te produkty od producentów rolnych, co najmniej 50\% zdolności przechowalniczych zakładu przeznaczonego do świadczenia usług w zakresie zamrażania i przechowywania produktów rolnych ( $\$ 4$ ust. 1 rozporządzenia).

Zobowiązanie się przetwórców do zaopatrywania się w produkty bezpośrednio u producenta niewątpliwie służy skracaniu łańcucha dostaw, oraz, w myśl uzasadnienia do rozporządzenia, ,wpływać będzie również na sytuację producentów rolnych, którzy ze względu na powiązania kontraktacyjne z zakładami przetwórczymi lub podmiotami prowadzącymi handel hurtowy uzyskają stabilizację zbytu produktów rolnych".

W ramach kolejnego działania „Premie dla młodych rolników” przewidziana została „Pomoc w rozpoczęciu działalności gospodarczej na rzecz młodych rolników", przyznawana w związku z rozpoczynaniem prowadzenia gospodarstwa rolnego. Wsparcie dotyczy rozwoju działalności rolniczej w gospodarstwie rolnym, 
a także przygotowania do sprzedaży wytwarzanych w gospodarstwie produktów rolnych. ${ }^{12} \mathrm{~W}$ tym wypadku również rozporządzenie nie precyzuje, czy chodzi o sprzedaż hurtową czy detaliczną, bezpośrednio konsumentowi końcowemu. Ale kryteria wyboru uwzględniające w szczególności m.in.: przetwarzanie produktów rolnych wytwarzanych w gospodarstwie, sugerują przygotowanie do sprzedaży bezpośredniej, bo tylko w jej ramach mogą być dostarczane produkty przetworzone w gospodarstwie. Wskazane warunki w połączeniu z brakiem wymogu prowadzenia lub rejestracji działalności gospodarczej wpisują się w treść znowelizowanego art. 3 u.s.d.g.

Rozporządzenie przewiduje, że biznesplan może określać nie tylko prowadzenie działań w zakresie przygotowania do sprzedaży produktów rolnych wytwarzanych $\mathrm{w}$ gospodarstwie lub prowadzenia działalności w zakresie przetwarzania produktów rolnych wytwarzanych w gospodarstwie, ale także uczestnictwo w unijnym systemie jakości, o którym mowa w art. 16 rozporządzenia nr 1305/2013 lub krajowym systemie jakości, o którym mowa w działaniu „Systemy jakości produktów rolnych i środków spożywczych" objętym Programem. ${ }^{13}$

Pomoc przeznaczona jest dla gospodarstw, które mają wielkość ekonomiczną nie mniejszą niż 13 tys. euro i nie większą niż 150 tys. euro. Preferowane są gospodarstwa o powierzchni użytków rolnych równej co najmniej średniej krajowej, a w przypadku gospodarstw położonych w województwie o średniej niższej niż krajowa - równą co najmniej średniej wojewódzkiej oraz nie większą niż 300 ha. Choć przedmiotem wsparcia są działalności, które nie podlegają opodatkowaniu, rozporządzenie przewiduje obowiązek prowadzenia ewidencji przychodów i rozchodów w gospodarstwie lub księgi przychodów i rozchodów, lub księgi rachunkowej, lub ewidencji przychodów i rozchodów na podstawie odrębnych przepisów, co najmniej do dnia upływu 5 lat od dnia wypłaty pierwszej raty pomocy.

Rolnik, który wytwarza produkty rolne i środki spożywcze w ramach unijnych lub krajowych systemów, jakości może skorzystać z działania „Systemy jakości produktów rolnych i środków spożywczych”, poddziałanie „Wsparcie na przystępowanie do systemów jakości”. Pomoc dotyczy uczestnictwa w unijnych systemach jakości, tj. Chronione Nazwy Pochodzenia, Chronione Oznaczenia Geograficzne; Gwarantowane Tradycyjne Specjalności; Rolnictwo ekologiczne oraz w Krajowych, takich jak 1. Integrowana produkcja roślin 2. System Jakość Tradycja 3. System jakości QMP; 4. System jakości QAFP w zakresie mięsa wieprzowego i wędlin 6. System jakości PQS. ${ }^{14}$

Zob. § 6 ust. 2 rozporządzenie Ministra Rolnictwa i Rozwoju Wsi z dnia 13 lipca 2015 r. w sprawie szczegółowych warunków i trybu przyznawania, wypłaty oraz zwrotu pomocy finansowej na operacje typu „Premie dla młodych rolników” w ramach poddziałania „Pomoc w rozpoczęciu działalności gospodarczej na rzecz młodych rolników” objętego Programem Rozwoju Obszarów Wiejskich na lata 2014-2020, Dz.U. z dnia 14 lipca 2015 r., poz. 982 Ibidem.

14 Zob. § 3 pkt 3 i 4 rozporządzenia Ministra Rolnictwa i Rozwoju Wsi z dnia 6 sierpnia 2015 r. w sprawie szczegółowych warunków i trybu przyznawania, wypłaty oraz zwrotu pomocy finansowej w ramach poddziałania „Wspar- 
Beneficjentem może być rolnik aktywny zawodowo w rozumieniu art. 9 rozporządzenia Parlamentu Europejskiego i Rady (UE) nr 1307/2013 ${ }^{15}$ oraz przepisów krajowych ${ }^{16}$ któremu została przyznana jednolita płatność obszarowa za rok poprzedzający złożenie wniosku oraz złoży oświadczenie o ubieganiu się o płatności przez okres pomocy. Rozporządzenie przewiduje, że o pomoc może ubiegać się także rolnik, który jest członkiem grupy producentów. ${ }^{17}$

Wsparcie polega na refundacji kosztów kwalifikowanych na podstawie kosztów rzeczywiście poniesionych $\mathrm{w}$ związku $\mathrm{z}$ funkcjonowaniem $\mathrm{w}$ ramach systemu (np. na kontrole i uzyskanie certyfikatu jakości). Zgodnie z uzasadnieniem do projektu rozporządzenia omawiana pomoc ma wesprzeć rolników w finansowaniu wyższych kosztów produkcji, do czasu kiedy koszty te będą odzwierciedlone w wyższej cenie tych produktów na rynku.

Warunki przyznania pomocy nie są uzależnione od wielkości gospodarstwa, mogą z niej zatem skorzystać także bardzo małe gospodarstwa, dla których koszty stałe, wynikające $\mathrm{z}$ udziału w systemach jakości, stanowią duże obciążenie finansowe. Można zauważyć, że jest to instrument skierowany do bardzo małych gospodarstw, nie mający jednak charakteru alimentacyjnego, jak w przypadku instrumentów w PROW 2004-2006, i nie wymagający zwiększenia powierzchni gospodarstw, jednak mogący przyczynić się do poprawy ich rentowności. Oczywiście, trwała poprawa może nastąpić przy założeniu, że po okresie dofinansowania sprzedawane produkty uzyskają renomę i zainteresowanie konsumentów, dzięki czemu koszty uczestnictwa w systemie będą mogły być zawarte w ich cenie.

W sprzedaży bezpośredniej ważne są działania informacyjne i promocyjne w celu dotarcia do konsumenta i zwrócenia jego uwagi na możliwość nabycia produktów prosto z gospodarstwa oraz na specyficzne cechy i jakość takich wyrobów. W PROW zostało przewidziane poddziałanie „Wsparcie działań informacyjnych i promocyjnych realizowanych przez grupy producentów na rynku wewnętrznym", ale tylko w odniesieniu do produktów rolnych lub środków spożywczych wytwarzanych w ramach systemów jakości. O środki może ubiegać się zespół „promocyjny” utworzony przez co najmniej dwóch producentów powyższych produktów. Pomoc

cie na przystępowanie do systemów jakości” objętego Programem Rozwoju Obszarów Wiejskich na lata 20142020, Dz.U. poz. 1195.

Rozporządzenie Parlamentu Europejskiego i Rady (UE) ustanawiającego przepisy dotyczące płatności bezpośrednich dla rolników na podstawie systemów wsparcia w ramach wspólnej polityki rolnej oraz uchylającego rozporządzenie Rady (WE) nr 637/2008 i rozporządzenie Rady (WE) nr 73/2009, Dz.Urz. L 347 z dnia 20 grudnia 2013 r.

Zob. ustawa z dnia 5 lutego 2015 r. o płatnościach w ramach systemów wsparcia bezpośredniego (Dz.U. poz. 1551).

17 Zob. § 8 ust. 2 pkt 4 rozporządzenia z dnia 6 sierpnia 2015 r. Załącznik do rozporządzenia podaje kwalifikujące się formy organizacyjne grup producentów. 
ma formę refundacji $70 \%$ kosztów poniesionych w celu przeprowadzenia działań promocyjnych. ${ }^{18}$

Kolejne poddziałanie, które ma m.in. na celu skracanie łańcucha żywnościowego, to „Tworzenie grup i organizacji producentów”. Według warunków określonych w PROW (brak rozporządzenia, stan na 15.10.2015 r.) beneficjentami są nowe grupy producentów rolnych, które powstały od dnia 1 stycznia 2014 r., działające jako przedsiębiorcy, składające się z osób fizycznych i które spełnią dodatkowe warunki kwalifikowalności. Wsparcie przeznaczone jest m.in. na wspólne wprowadzanie towarów do obrotu, w tym przygotowania do sprzedaży, centralizacji sprzedaży i dostawy do odbiorców hurtowych. Przepisy w zakresie sprzedaży bezpośredniej nie przewidują prowadzenia przetwarzania bądź sprzedaży bezpośredniej wspólnie przez rolników. Dlatego w ramach grupy rolnik może dostarczać jedynie produkty nieprzetworzone. Warunki działania przewidują preferencje w przyznawaniu pomocy dla grup i organizacji producentów, zorganizowanych w formie spółdzielni i zrzeszających producentów w wybranych kategoriach produktów rolnych (głównie zwierzęta i mięso). Działanie grupowe nie pozwala na prowadzenie przez rolników sprzedaży bezpośredniej, ale niewątpliwie służy skracaniu łańcucha dostaw. Ponadto pozwala na zwiększenie konkurencyjności producentów rolnych i ich pozycji w łańcuchu dostaw, poprzez wspólne planowanie, organizowanie produkcji oraz ponoszenie kosztów przechowywania i transportu, a także wzbogacenie oferty sprzedaży i dostosowanie jej do potrzeb odbiorców.

Poddziałanie „Wsparcie tworzenia i działania grup operacyjnych EPI na rzecz wydajnego i zrównoważonego rolnictwa" (w ramach działania Współpraca) dotyczy wspierania powstawania i działalności grup operacyjnych na rzecz innowacji (EPI) w rozumieniu art. 56 i 57 Rozporządzenia UE 1305/2013, które w ramach działalności będą realizować projekty polegające na opracowywaniu i wdrażaniu rozwiązań innowacyjnych do praktyki. Przedmiotem operacji realizowanych przez grupę operacyjną na rzecz innowacji mogą być produkty oraz praktyki, procesy i technologie związane z produkcją lub przetwarzaniem produktów rolnych. Według założenia PROW „największe korzyści ostatecznie odniosą, w wyniku realizacji działania, producenci rolni, zwiększając w dłuższej perspektywie swoją konkurencyjność, dochodowość i uczestnictwo w rynku, zgodnie z celem szczegółowym $2 \mathrm{~A}$ ". ${ }^{19}$

Chociaż założeniem WPR w ramach współpracy było umożliwienie, jak wyraźnie stanowi art. 35 rozporządzenia 1305/2013, horyzontalnej i wertykalnej współpracy między podmiotami łańcucha dostaw na rzecz utworzenia i rozwoju krótkich łańcuchów dostaw i rynków lokalnych, czyli finansowania operacji także w zakre- 
sie wspólnego organizowania zbytu produktów rolnych, jednak w polskim PROW operacje ograniczają się do procesu produkcji i przetwarzania produktów rolnych.

Eksperci europejskiej sieci na rzecz obszarów wiejskich stwierdzili, że „Partnerstwo i współpraca są i będą w dalszym ciągu kluczem do sukcesu w tworzeniu lokalnych systemów żywnościowych i krótkich łańcuchów dostaw ${ }^{20}$ ". Dlatego ważne jest wsparcie operacji zakładających szerokie partnerstwo producentów, konsumentów, podmiotów sektora publicznego i organizacji dla tworzenia lokalnych systemów żywnościowych i krótkich łańcuchów dostaw, jak np. powiązania kontraktacyjne między lokalnymi producentami a instytucjami publicznymi (szkoły, szpitale) prowadzącymi stołówki, restauracjami, sklepami spożywczymi w zakresie zaopatrzenia w lokalne produkty rolne.

Środki na operacje zakładające stworzenie sieci w zakresie realizacji krótkich łańcuchów dostaw i rynków lokalnych oraz działań promocyjnych i marketingowych zostały przewidziane w programie LEADER. Działanie „Wsparcie dla rozwoju lokalnego w ramach inicjatywy LEADER (RLKS - rozwój lokalny kierowany przez społeczność) skierowane jest na operacje mające m.in. na celu rozwój produktów lokalnych, rozwój rynków zbytu, z wyłączeniem targowisk i zachowanie dziedzictwa lokalnego. Pomoc nie jest przyznawana na operacje służące zaspokajaniu partykularnych potrzeb beneficjenta (lub beneficjenta ostatecznego); promocję indywidualnych przedsiębiorców, ich produktów i usług.

W przypadku operacji z zakresu tworzenia i funkcjonowania sieci, operacja realizowana jest przez co najmniej dwóch partnerów, których działalność jest ukierunkowana na tworzenie krótkich łańcuchów dostaw, rynków lokalnych lub usług turystycznych. Beneficjentami mogą być osoby fizyczne, osoby prawne i jednostki organizacyjne nieposiadające osobowości prawnej. Ponadto, w przypadku operacji mających na celu rozpoczęcie lub rozwój działalności pozarolniczej, pomoc może być przyznana osobom fizycznym ubezpieczonym na podstawie przepisów o ubezpieczeniu społecznym rolników w niepełnym zakresie, którzy obok rolniczej prowadzą działalność pozarolniczą. W przypadku operacji w zakresie przetwórstwa lub sprzedaży produktów rolnych beneficjentem może być również osoba fizyczna ubezpieczona na podstawie przepisów o ubezpieczeniu społecznym rolników w pełnym zakresie.

W ramach poddziałania „Wsparcie na wdrażanie operacji w ramach strategii rozwoju lokalnego kierowanego przez społeczność" pomoc, w myśl $§ 2$ ust. 1 pkt 3-5 rozporządzenia ${ }^{21}$ przyznawana jest m.in. na operacje wspierania współpracy 
między podmiotami wykonującymi działalność gospodarczą na obszarze wiejskim objętym $\operatorname{LSR}^{22} \mathrm{w}$ ramach krótkich łańcuchów dostaw, a także w zakresie rozwijania rynków zbytu produktów lub usług lokalnych, w tym gminy oraz jednostki organizacyjne nieposiadające osobowości prawnej. Zgodnie z $§ 10$ ust. 1 podmioty muszą zawrzeć porozumienie o wspólnej realizacji operacji, która ma na celu zwiększenie sprzedaży dóbr lub usług oferowanych przez podmioty z obszaru wiejskiego objętego LSR przez zastosowanie wspólnego znaku towarowego lub stworzenie oferty kompleksowej sprzedaży takich dóbr lub usług.

W PROW 2014-2020 zostało przewidziane ponadto wsparcie na realizację kursów dla rolników m.in. z zakresu marketingu, rachunkowości, skracania łańcucha żywnościowego, w ramach działania „Wsparcie kształcenia zawodowego i nabywania umiejętności”, o które mogą ubiegać się jednostki naukowe i uczelnie, publiczne podmioty doradcze, tj. wojewódzkie ośrodki doradztwa rolniczego, Centrum Doradztwa Rolniczego, izby rolnicze oraz inne podmioty prowadzące działalność szkoleniową.

Środki zostały również przewidziane na świadczenie usług doradczych (porad) dla rolników lub grupy rolników w ramach działania „Usługi doradcze, usługi z zakresu zarządzania gospodarstwem i usługi z zakresu zastępstw", poddziałanie „Świadczenie kompleksowej porady dla rolnika”. Porada dla rolników może m.in. obejmować kwestie wyników ekonomicznych gospodarstwa rolnego w zakresie oddziaływania na środowisko, w tym aspektów dotyczących konkurencyjności (np. krótkie łańcuchy dostaw, rolnictwo ekologiczne, aspekty zdrowotne chowu zwierząt); oraz innych zagadnień, wynikających z potrzeb gospodarstwa rolnego ostatecznego odbiorcy.

W PROW 2014-2020 zostało przewidziane wielokierunkowe wsparcie krótkich łańcuchów dostaw, w tym sprzedaży bezpośredniej i przetwarzania produktów wytwarzanych w gospodarstwach, zarówno na rzecz indywidualnych rolników, a także grup rolników oraz podmiotów prowadzących działalność gospodarczą w zakresie przetwórstwa i sprzedaży.

Cztery poddziałania („Pomoc na rozpoczęcie działalności gospodarczej na rzecz rozwój małych gospodarstw”, „Wsparcie inwestycji w gospodarstwach rolnych”, „Wsparcie inwestycji w przetwarzanie i obrót”, „Pomoc w rozpoczęciu inwestycji na rzecz młodych rolników") przeznaczone są dla rolników na inwestycje związane z przetwarzaniem produktów rolnych, ale także z przygotowaniem do sprzeda-

strategii rozwoju lokalnego kierowanego przez społeczność" objętego Programem Rozwoju Obszarów Wiejskich na lata 2014-2020, Dz.U. poz. 1570. 
ży produktów wytarzanych w gospodarstwie, bez obowiązku rejestracji działalności gospodarczej, wpisując się w ten sposób w treść znowelizowanego art. 3 u.s.d.g.

Spośród wymienionych czterech działań, jedynie „Wsparcie inwestycji w przetwarzanie produktów rolnych, obrót nimi lub ich rozwój” nie określa wymogów w zakresie wielkości gospodarstwa, wzrostu jego wielkości ekonomicznej, udokumentowania wykonywania przez min. 12 miesięcy, przed przystąpieniem do poddziałania, zarobkowej działalności sprzedaży produktów rolnych oraz prowadzenia, po uzyskaniu wsparcia ewidencji przychodów i rozchodów w gospodarstwie lub księgi przychodów i rozchodów, lub księgi rachunkowej. Wymienione warunki, a zwłaszcza dwa ostatnie mogą stanowić problem, szczególnie dla małych gospodarstw, do których skierowane jest działanie „Pomoc na rozpoczęcie działalności gospodarczej na rzecz rozwoju małych gospodarstw". Wymóg prowadzenia rachunkowości przewidziany w powyższych działaniach ma zapewne być sprawdzianem przed ewentualnym wprowadzeniem dla rolników w przyszłości powyższego obowiązku w sposób systemowy.

Innym działaniem na rzecz małych gospodarstw, wartym docenienia, bo pozwalającym wykorzystać tkwiący w nich potencjał, jest „Wsparcie na przystępowanie do systemów jakości”. Pozytywnie należy także ocenić wsparcie na budowę targowisk, przeznaczonych w przeważającej mierze dla rolników.

Innym, ważnym instrumentem sprzyjającym skracaniu łańcucha dostaw jest, określony w działaniu „Wsparcie inwestycji w przetwarzanie produktów rolnych, obrót nimi lub ich rozwój”, obowiązek zaopatrywania się przetwórców w surowce rolne, na podstawie 3-letnich umów, bezpośrednio u producentów, a także poddziałanie „Tworzenie grup i organizacji producentów” wzmacniające pozycję producentów rolnych w łańcuchach żywnościowych. Również inwestycje w ramach działania LEADER mają służyć budowie sieci w celu tworzenia lokalnych systemów żywnościowych.

Dzięki powyższym działaniom jest szansa, że krótkie łańcuchy dostaw i lokalne systemy żywnościowe, które są ważnym elementem obszarów wiejskich, ale także tradycji i tożsamości narodowej, przestaną być jedynie marginalne, ale staną się bardziej znaczącym elementem produkcji rolnej w Polsce. Przydatne byłoby rozszerzenie wsparcia na działania informacyjne i promocyjne nie tylko w odniesieniu do produktów rolnych lub środków spożywczych wytwarzanych w ramach systemów jakości, ale na wszystkie lokalne produkty pochodzące bezpośrednio od rolnika. Ponadto prawne określenie dla nich jednolitego oznaczenia, wskazującego na ich pochodzenie, przyczyniłoby się do ich promocji, lepszej komunikacji i poprawy świadomości konsumentów. W tym kontekście należy pozytywnie ocenić pomoc na stworzenie wspólnego znaku towarowego przez lokalną społeczność kierującą strategią rozwoju lokalnego, który choć będzie ograniczał się do produktów 
Prawne uwarunkowania wsparcia krótkich łańcuchów dostaw żywności w PROW 2014-2020

lokalnych z jednego obszaru, na pewno pozwoli na ich wyróżnienie i dostrzeżenie przez konsumentów. 
LEGAL CONDITIONS OF SHORT FOOD SUPPLY CHAINS SUPPORT IN THE RURAL DEVELOPMENT PROGRAMME FOR 2014 - 2020

Keywords: short food supply chains, the Rural Development Programme, direct sales

The aim of the paper is to present forms of shortening the food chain, which are being supported in the Rural Development Program 2014-2020 and to determine whether the legal conditions to obtain the financial support are consistent with the legislation, especially with the amended regulations on direct sales. Four actions (,Help to start a business for the development of small farms”, ,Support for investment in agricultural holdings”, „Support for investments in processing and marketing,” „Help in start-up investments for young farmers”) are intended for farmers for investments related to agricultural processing and preparation for the sale, without the obligation to register a business, fitting into the content of the amended Art. 3 of Law on Freedom of Economic Activity. „Creating groups and producers' organizations”, „Cooperation”, „Leader”, are aimed at integrating stakeholders in the food chain, strengthen the position of the agricultural producer in the food chain and contribute to building a local food system. On this basis there is a chance that the short chains and local food production will become more significant in the food system in Poland. 